\title{
Rating of the Central Federal District by Key Parameters of Economic Development
}

\author{
Gusev A.Yu. \\ Faculty of Economics and Management \\ Ryazan State Agrotechnological University Named after P.A. Kostychev \\ Ryazan, Russia \\ e-mail: ay.gusev@mail.ru
}

\begin{abstract}
The purpose of the study is a comparative assessment of the current level of development of agriculture in regions on the basis of the proposed rating, focused on a number of key indicators, such as the number of animals, production volumes, crop yields (animal productivity), etc. In the process of the study, the following methods were used: monographic, analytical, system analysis and rating. The proposed rating algorithm allows identifying the most successful and lagging regions in its development, focuses on the adoption of effective managerial decisions aimed at positive economic results and a steady increase in the level of socio-economic well-being of the agricultural sector of the regions.
\end{abstract}

Keywords — rating, score, region, integral indicator, ranking, rank.

\section{INTRODUCTION}

The Central Federal District is a key region of the Russian Federation, which is characterized by a high level of economic, technological, and innovative development, where special attention is paid to the agro-industrial complex from the side of regional authorities. It includes a number of areas producing a variety of agricultural products, in particular grain, meat, milk, feed. The scale of production activity in each region should be estimated by the level of this or that economic indicator. For example, in the livestock sector it is the size of the livestock, livestock (meat) production, milk yield per cow and growth in cattle. In crop production it can be yield, sown area, farmland area and other parameters characterizing the economic condition of industries, giving each of them a rating score. Rating methods were applied by foreign scientists, for example, in the field of assessing the state of indicators of the national economy [5], the state of the environmental situation [6, 9], sounding models and agricultural land valuation [2]. In Russian scientific developments, ratings were also used in assessing the level of development of sectors of the national economy, including agriculture. In particular, based on a specific set of parameters, the socio-economic potential of the territories [16], socioeconomic processes [13], innovation and investment analysis and management of the sectoral economy $[1,10,14,15]$ were studied. The sectoral parameters of agricultural efficiency $[4,7,8,12]$ and food safety [11] were proposed. The comparative rating score according to key parameters of the development of the regional agro-industrial complexes, conducted in these studies is designed to expand the range of scientific developments in this direction.

\section{RESULTS AND DISCUSSION}

The rating of the Central Federal District (CFD) regions according to the main parameters of the economic development of the livestock industry was based on a point estimate at the beginning of 2019. As an example, the number of cattle, cows, pigs, sheep and goats in the regions was taken as one of the assessment criteria. Based on this time series ranking was performed in the order of decreasing the criterion, i.e. the lower the indicator, the higher the score. One can also use the ranking of the series in the opposite direction: the higher the indicator, the higher the score. In the first case, the highest rank is assigned to the region that has the fewer points scored, in the second case, it is vice versa, the more points, the higher the rating. In our example, the ranking was carried out according to the first method, i.e. the region with the lowest number of points was assigned the highest rating (Table 1).

TABLE I. RATING OF REGIONS BY LIVESTOCK, THOUSAND HEADS

\begin{tabular}{|c|c|c|c|c|c|c|c|c|c|c|}
\hline \multirow[t]{2}{*}{ Region } & \multirow[b]{2}{*}{$\underbrace{\stackrel{0}{*}}_{\tilde{E}}$} & \multirow[b]{2}{*}{ 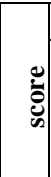 } & \multicolumn{6}{|c|}{ including } & \multirow[b]{2}{*}{ 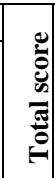 } & \multirow[b]{2}{*}{$\frac{\mathbb{\Xi}}{\mathbf{\Xi}}$} \\
\hline & & & $\frac{2}{8}$ & : & $\stackrel{0}{0}$ & 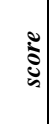 & 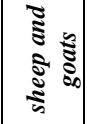 & 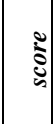 & & \\
\hline \multicolumn{11}{|l|}{ CFD regions } \\
\hline 1. Belgorod region & 223.9 & 3 & 88.2 & 4 & $4,362.8$ & 1 & 98.4 & 3 & 11 & 2 \\
\hline 2. Bryansk region & 462.6 & 2 & 195.4 & 1 & 295.5 & 10 & 29.8 & 14 & 27 & 5 \\
\hline 3. Vladimir region & 133.8 & 9 & 57.4 & 7 & 41.7 & 14 & 25.4 & 16 & 46 & 13 \\
\hline 4. Voronezh region & 463.7 & 1 & 178.5 & 2 & $1,169.3$ & 3 & 235.1 & 1 & 7 & 1 \\
\hline 5. Ivanovo region & 67.4 & 16 & 29.1 & 16 & 12.0 & 16 & 25.6 & 15 & 63 & 16 \\
\hline 6. Kaluga region & 159.5 & 7 & 68.3 & 5 & 108.9 & 12 & 41.6 & 11 & 35 & 9 \\
\hline 7. Kostroma region & 53,6 & 17 & 23.4 & 17 & 36.7 & 15 & 18.6 & 17 & 66 & 17 \\
\hline 8. Kursk region & 162.3 & 6 & 57.3 & 8 & $1,688.8$ & 2 & 98.6 & 2 & 18 & 3 \\
\hline 9. Lipetsk region & 115.0 & 11 & 45,2 & 12 & 681.5 & 5 & 71.3 & 5 & 33 & 7 \\
\hline 10. Moscow region & 213.2 & 4 & 99.3 & 3 & 321.0 & 8 & 63.6 & 6 & 21 & 4 \\
\hline 11. Orel region & 147.2 & 8 & 41.5 & 13 & 404.3 & 7 & 59.2 & 7 & 35 & 8 \\
\hline 12. Ryazan region & 165.4 & 5 & 66.6 & 6 & 219.1 & 11 & 59.9 & 8 & 30 & 6 \\
\hline 13. Smolensk region & 108.4 & 13 & 55.9 & 9 & 309.2 & 9 & 30.4 & 13 & 44 & 12 \\
\hline 14. Tambov region & 100.2 & 15 & 39.2 & 14 & 986.2 & 4 & 79.7 & 4 & 37 & 10 \\
\hline 15. Tver region & 106,2 & 14 & 48.8 & 11 & 582.0 & 6 & 45.1 & 10 & 41 & 11 \\
\hline 16. Tula region & 109.2 & 12 & 35.4 & 15 & 83.8 & 13 & 52.7 & 9 & 49 & 15 \\
\hline 17. Yaroslavl region & 117.5 & 10 & 51.0 & 10 & 6.1 & 17 & 33.1 & 12 & 49 & 14 \\
\hline
\end{tabular}

The rating estimation of the number of animals in regions of the Central Federal District revealed that Voronezh Region (7 scores), which has the largest number of livestock, received the first place in the rating. It indicates a significant scale of livestock production compared to other regions that are part of the Central Federal District. This region has the highest 
volumes of livestock production. The second place in the rating is taken by Belgorod region (11 scores), Kursk region takes the third place (18 scores) and Moscow region takes the fourth place ( 21 scores). Last places in the rating are taken by Kostroma (66 scores) and Ivanovo regions (63 scores) having the least concentrated livestock of production animals. In case of equality of the scores, the highest rank is assigned to the region having a large number of livestock giving the most socially significant types of products, for example, cattle breeding, which gives meat and milk.

Let us conduct a rating assessment of the regions according to the criterion of gross livestock production by type: livestock and poultry for slaughter (carcass weight), milk and eggs, using the inverse scoring system with the principle the higher the indicator, the higher the score (Table 2).

TABLE II. RATING OF REGIONS BY GROSS LIVESTOCK PRODUCTION

\begin{tabular}{|c|c|c|c|c|c|c|c|c|}
\hline \multirow[t]{2}{*}{ Region } & \multicolumn{2}{|c|}{$\begin{array}{l}\text { Livestock and } \\
\text { poultry for } \\
\text { slaughter } \\
\text { (carcass weight) }\end{array}$} & \multicolumn{2}{|c|}{ Milk } & \multicolumn{2}{|c|}{ Eggs } & \multirow[t]{2}{*}{ 离 } & \multirow[t]{2}{*}{$\frac{\mathbb{E}}{\tilde{E}}$} \\
\hline & thous. $t$ & score & thous. $t$ & score & mln.pcs. & score & & \\
\hline \multicolumn{9}{|l|}{ CFD regions } \\
\hline 1. Belgorod region & $1,332.9$ & 17 & 593.6 & 15 & $1,662.1$ & 16 & 48 & 1 \\
\hline 2. Bryansk region & 316.0 & 14 & 293.6 & 10 & 386.4 & 9 & 33 & 5 \\
\hline 3. Vladimir region & 48,0 & 4 & 386.3 & 13 & 541.7 & 12 & 29 & 8 \\
\hline 4. Voronezh region & 287.6 & 13 & 841.5 & 17 & 947.9 & 15 & 45 & 2 \\
\hline 5. Ivanovo region & 24.7 & 2 & 163.2 & 2 & 394.3 & 10 & 14 & 17 \\
\hline 6. Kaluga region & 80.4 & 7 & 305.9 & 11 & 138.6 & 5 & 23 & 10 \\
\hline 7. Kostroma region & 14.1 & 1 & 108.4 & 1 & 812.9 & 14 & 16 & 16 \\
\hline 8. Kursk region & 401.7 & 16 & 286.9 & 9 & 133.1 & 4 & 29 & 7 \\
\hline 9. Lipetsk region & 264.3 & 12 & 257.5 & 8 & 60.7 & 1 & 21 & 12 \\
\hline 10. Moscow region & 228.0 & 11 & 647.9 & 16 & 139.3 & 6 & 33 & 4 \\
\hline 11. Orel region & 100.4 & 9 & 170.1 & 4 & 124.0 & 3 & 16 & 15 \\
\hline 12. Ryazan region & 46.9 & 3 & 399.0 & 14 & 758.9 & 13 & 30 & 6 \\
\hline 13. Smolensk region & 65.0 & 6 & 198.7 & 6 & 215.0 & 8 & 20 & 13 \\
\hline 14. Tambov region & 359.3 & 15 & 194.9 & 5 & 151.5 & 7 & 27 & 9 \\
\hline 15. Tver region & 139.7 & 10 & 217.4 & 7 & 99.7 & 2 & 19 & 14 \\
\hline 16. Tula region & 94.6 & 8 & 170.0 & 3 & 467.2 & 11 & 22 & 11 \\
\hline 17. Yaroslavl region & 63.7 & 5 & 309.6 & 12 & $1,979.3$ & 17 & 34 & 3 \\
\hline
\end{tabular}

Livestock production volumes change under the influence of two important indicators, such as productivity and average annual number of animals. Current trends in the dairy cattle industry, for example, indicate that with a decreasing dairy livestock, its productivity is growing at the same time. So, in this case it is very important that the growth rate of productivity outstrips the rate of reduction in the number of animals. Only in this case it is possible to reach the increase in milk production. In the study, the key place in the production of livestock products is occupied by Belgorod (48 scores), Voronezh (45 scores) and Yaroslavl regions (34 points), they occupy the highest ranks, respectively, 1st, 2nd and 3rd places. The experience of these regions should be taken as a basis in developing a strategy for the development of the livestock industry in the Central Federal District.

Let us carry out a rating assessment of the crop production industry by regions of the Central Federal District. As a basis, the criterion of gross harvests of the main crops is taken (Table 3). The lowest score in this option will be related to the highest indicator. So the region, that gets the lowest score, will take the highest rating.
TABLE III. RATING OF REGIONS BY GROSS HARVEST OF MAIN AGRICULTURAL CROPS, THOUSAND TONS

\begin{tabular}{|c|c|c|c|c|c|c|c|c|}
\hline \multirow[t]{2}{*}{ Region } & \multicolumn{2}{|c|}{$\begin{array}{l}\text { grain } \\
\text { crops }\end{array}$} & \multicolumn{2}{|c|}{ potato } & \multicolumn{2}{|c|}{ vegetables } & \multirow{2}{*}{ 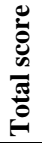 } & \multirow{2}{*}{$\frac{\mathscr{E}}{2}$} \\
\hline & thous. $t$ & score & thous. $t$ & score & thous. $t$ & score & & \\
\hline \multicolumn{9}{|l|}{ CFD regions } \\
\hline 1. Belgorod region & $3,584.8$ & 4 & 515.5 & 7 & 248.2 & 3 & 14 & 2 \\
\hline 2. Bryansk region & $1,710.3$ & 9 & $1,490.2$ & 1 & 162.2 & 6 & 16 & 6 \\
\hline 3. Vladimir region & \begin{tabular}{|l|}
222.4 \\
\end{tabular} & 12 & 265.3 & 12 & 147,9 & 7 & 31 & 11 \\
\hline 4. Voronezh region & $5,663.9$ & 1 & $1,449.6$ & 2 & 534.5 & 2 & 5 & 1 \\
\hline 5. Ivanovo region & \begin{tabular}{|l|}
129.3 \\
\end{tabular} & 14 & 132.0 & 17 & 70.4 & 16 & 47 & 17 \\
\hline 6. Kaluga region & 218.7 & 13 & 325.8 & 11 & 132.4 & 8 & 32 & 12 \\
\hline 7. Kostroma region & 41.6 & 17 & 141.6 & 16 & 104.5 & 11 & 44 & 16 \\
\hline 8. Kursk region & $5,034.1$ & 2 & 875.6 & 4 & 130.2 & 9 & 15 & 3 \\
\hline 9. Lipetsk region & $3,134.3$ & 6 & 699.8 & 6 & 190.0 & 4 & 16 & 4 \\
\hline 10. Moscow region & \begin{tabular}{|l|}
426.8 \\
\end{tabular} & 10 & 778.0 & 5 & 548.3 & 1 & 16 & 7 \\
\hline 11. Orel region & $3,179.8$ & 5 & 419.2 & 9 & 71.5 & 15 & 29 & 8 \\
\hline 12. Ryazan region & $2,083.4$ & 7 & 352.7 & 10 & 99.9 & 12 & 29 & 10 \\
\hline 13. Smolensk region & 242.5 & 11 & 201.7 & 14 & 66.4 & 17 & 42 & 14 \\
\hline 14. Tambov region & $4,143.6$ & 3 & 496.1 & 8 & 97.9 & 13 & 24 & 8 \\
\hline 15. Tver region & \begin{tabular}{|l|}
99.8 \\
\end{tabular} & 15 & 219.4 & 13 & 94.0 & 14 & 42 & 15 \\
\hline 16. Tula region & $1,870.8$ & 8 & 909.1 & 3 & 170.1 & 5 & 16 & 5 \\
\hline 17. Yaroslavl region & 79.8 & 16 & 180.2 & 15 & 109.1 & 10 & 41 & 13 \\
\hline
\end{tabular}

In a case of equal scores in 4 regions (16 scores), a qualitative assessment of products is taken into account. Grain plays an important role as the most popular product at foreign and domestic markets. It is of strategic importance for the country. Given the volume of grain production, places are given in the dynamic row. For example, Lipetsk region had the largest grain harvest among three competitors for this place, so it gets the highest rating position - the 4th place. According to the results of the rating assessment, the highest places are occupied respectively by Voronezh, Belgorod and Kursk regions which gained the least number of scores. One of the important parameters characterizing the level of agricultural efficiency in the regions is a qualitative indicator crop productivity, assigning the highest number of scores to the best yield indicator (Table 4).

TABLE IV. RATING OF REGIONS BY THE YIELD OF MAIN AGRICULTURAL CROPS, DT/HA

\begin{tabular}{|l|c|c|c|c|c|c|c|c|}
\hline \multirow{2}{*}{ Region } & \multicolumn{2}{|c|}{ grain crops } & \multicolumn{2}{c|}{ potato } & \multicolumn{2}{c|}{ vegetables } & Total & Place \\
& yield & score & yield & score & yield & score & score & \\
\hline CFD regions & & & & & & & & \\
\hline 1. Belgorod region & 48.0 & 16 & 122.3 & 3 & 117.1 & 1 & 20 & 13 \\
\hline 2. Bryansk region & 44.7 & 15 & 276.4 & 17 & 226.7 & 11 & 43 & 1 \\
\hline 3. Vladimir region & 25.9 & 7 & 116.1 & 2 & 145.4 & 2 & 11 & 17 \\
\hline 4. Voronezh region & 39.4 & 12 & 182.9 & 14 & 238.1 & 13 & 39 & 2 \\
\hline 5. Ivanovo region & 21.6 & 4 & 141.4 & 6 & 219.7 & 10 & 20 & 14 \\
\hline 6. Kaluga region & 24.6 & 6 & 152.0 & 8 & 205.8 & 8 & 22 & 12 \\
\hline 7. Kostroma region & 13.6 & 1 & 140.6 & 5 & 283.1 & 17 & 23 & 10 \\
\hline 8. Kursk region & 50.4 & 17 & 164.3 & 12 & 155.1 & 4 & 33 & 5 \\
\hline 9. Lipetsk region & 41.8 & 14 & 156.9 & 11 & 177.4 & 7 & 32 & 6 \\
\hline 10. Moscow region & 29.9 & 8 & 184.1 & 15 & 259.8 & 16 & 39 & 4 \\
\hline 11. Orel region & 37.4 & 11 & 158.8 & 10 & 172.8 & 6 & 27 & 8 \\
\hline 12. Ryazan region & 36.2 & 10 & 152.7 & 9 & 155.0 & 3 & 22 & 11 \\
\hline 13. Smolensk region & 21.7 & 5 & 129.2 & 4 & 213.6 & 9 & 18 & 15 \\
\hline 14. Tambov region & 40.7 & 13 & 169.9 & 13 & 160.2 & 5 & 31 & 7 \\
\hline 15. Tver region & 14.4 & 2 & 105.2 & 1 & 233.9 & 12 & 15 & 16 \\
\hline 16. Tula region & 32.5 & 9 & 215.7 & 16 & 238.5 & 14 & 39 & 3 \\
\hline 17. Yaroslavl region & 19.1 & 3 & 141.8 & 7 & 252.5 & 15 & 25 & 9 \\
\hline
\end{tabular}


The yield rating by region of the Central Federal District made it possible to determine the regions with the highest yield, assigning them the highest score. As a result of such a method, the most effective yield regions are Bryansk, Voronezh and Tula regions, which received the highest scores, taking respectively 1 st, 2 nd and 3rd places in the rating.

TABLE V. INTEGRATED RATING OF REGIONS

\begin{tabular}{|c|c|c|c|c|c|c|}
\hline \multirow[t]{2}{*}{ Region } & livestock & $\begin{array}{c}\text { livestock } \\
\text { production }\end{array}$ & $\begin{array}{c}\text { gross } \\
\text { yield of } \\
\text { major } \\
\text { crops } \\
\end{array}$ & $\begin{array}{c}\text { crop } \\
\text { yields }\end{array}$ & \multirow[t]{2}{*}{ 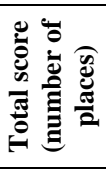 } & \multirow[t]{2}{*}{$\frac{\mathbb{E}}{\mathbb{E}}$} \\
\hline & rating & rating & rating & rating & & \\
\hline \multicolumn{7}{|l|}{ CFD regions } \\
\hline 1. Belgorod region & 2 & 1 & 2 & 13 & 18 & 3 \\
\hline 2. Bryansk region & 5 & 5 & 6 & 1 & 17 & 2 \\
\hline 3. Vladimir region & 13 & 8 & 11 & 17 & 49 & 13 \\
\hline 4. Voronezh region & 1 & 2 & 1 & 2 & 6 & 1 \\
\hline 5. Ivanovo region & 16 & 17 & 17 & 14 & 64 & 17 \\
\hline 6. Kaluga region & 9 & 10 & 12 & 12 & 43 & 12 \\
\hline 7. Kostroma region & 17 & 16 & 16 & 10 & 59 & 16 \\
\hline 8. Kursk region & 3 & 7 & 3 & 5 & 18 & 4 \\
\hline 9. Lipetsk region & 7 & 12 & 4 & 6 & 29 & 6 \\
\hline 10. Moscow region & 4 & 4 & 7 & 4 & 19 & 5 \\
\hline 11. Orel region & 8 & 15 & 8 & 8 & 39 & 10 \\
\hline 12. Ryazan region & 6 & 6 & 10 & 11 & 33 & 7 \\
\hline 13. Smolensk region & 12 & 13 & 14 & 15 & 54 & 14 \\
\hline 14. Tambov region & 10 & 9 & 8 & 7 & 34 & 9 \\
\hline 15. Tver region & 11 & 14 & 15 & 16 & 56 & 15 \\
\hline 16. Tula region & 15 & 11 & 5 & 3 & 34 & 8 \\
\hline 17. Yaroslavl region & 14 & 3 & 13 & 9 & 39 & 11 \\
\hline
\end{tabular}

Thus, an integrated comparative assessment of the regional effectiveness is based on all the above parameters, arranged by rank in the order of the number of scores. The volumes of livestock production, livestock, gross yield and yield of main agricultural crops, the rating assessment of which was carried out above (Table 5), were taken as evaluation criteria.

In previous calculations, a higher rating was assigned to regions having the best indicators. Thus, the highest rating was assigned to the region with the lowest number of scores (places). In a case of an equal number of scores, the highest rating was given to the region that showed the best results in terms of quality indicators. In our case, the yield of crops is qualitative among the list of parameters. That is why according to this criterion the regions will be ranked keeping in mind the principle - the higher the yield, the higher the rating. As a result of an integrated assessment of the rating of regions according to a number of criteria, the first place is taken by Voronezh region (6 scores), the second place belongs to Bryansk region ( 17 scores), the third one is Belgorod region (18 scores) and the lowest lines in the rating are Tver region (56 scores), Kostroma region (59 scores) and Ivanovo region (64 scores), which can be considered regions with low effective agriculture.

\section{CONCLUSION}

The proposed calculation algorithm makes it possible to evaluate the levels of economic development of the agroindustrial complex in the regions, draw analytical conclusions and develop recommendations aimed at the economic growth of the lagging regions. Taking into account the results of the rating, in prospective developments and strategic plans for the economic and financial activities of the regions, one can be guided by the developments of scientists studying the level of development of the advanced regions of the Russian Federation [17]. This methodology is universal and can be applied in all sectors of the national economy. The main feature of the rating assessment is the set of parameters on the basis of which it will be conducted. The important indicator that should certainly be taken into account in the rating assessment is meat production volumes, as cattle meat is one of the main food products of the population and the most important source of protein [3], the production of which in recent years in many regions of the country remains at a low level. Other parameters for evaluating the performance of activities can and should be applied in the ranking of regions. These are not static parameters, they tend to be updated and supplemented taking into account the specifics of the current situation and requirements of time. Moreover, the wider the range of indicators in the rating system, especially those reflecting the qualitative side of the problem under study are, the more reliable results of the study are.

\section{References}

[1] A.V. Agibalov, Y.V. Tkacheva, L.A. Zaporozhtseva, "Improvement of the financial management strategy for agricultural enterprises", Int. J. of Econ. Perspect., vol. 11, no. 3, pp. 1686-1696, 2018.

[2] M. Brklacich, P. Curran, D. Brunt "View Correspondence (jump link) The application of agricultural land rating and crop models to CO2 and climate change issues in Northern regions: The Mackenzie Basin case study", Agricult. and Food Sci. in Finland, vol. 5, iss. 3, pp. 351-365, 1996.

[3] E. Metelkova, G. Demishkevich, A. Gusev, "State support for the production of cattle meat: the experience of countries with high levels of self-sufficiency", IOP Conf. Ser. Earth and Environmental Sci., vol. 274, p. 012036, 2019. DOI: 10.1088/1755-1315/274/1/012036

[4] S.A. Gorlanov, Z.P. Medelyaeva, V.B. Malitskaya, M.B. Chirkova, E.I. Kostyukova, "Content analysis the term "effectiveness" and the concepts of its quantitative characteristics", Indo Amer. J. of Pharmac. Sci., vol. 6, no. 3, pp. 5293-5298, 2019.

[5] M. Hazuda, V. Gotra, L. Hazuda, "Advancing the convergence and integration of rural border areas", Econ. Annals-XXI, vol. 162, no. 11-12, pp. 18-21, 2017.

[6] D.M. Howard, B.K. Wylie, L.L. Tieszen, "Crop classification modelling using remote sensing and environmental data in the Greater Platte River Basin, USA", Int. J. of Remote Sens., vol. 33, no. 19, pp. 6094-6108, 2012.

[7] M. Korsun, "Rating assessment of the potential use of rural areas", IOP Conf. Ser. Earth and Environmental Sci., vol. 274, no. 1, p. 012069 , 2019.

[8] S. Lobova, "Methodological foundations for constructing a ranking of territories according to the level of efficiency of agricultural production”, Int. Agricult. J., no. 1, pp. 12-17, 2006.

[9] M. Milano, D. Ruelland, S. Fernandez, G. Thivet, E. Servat, “Assessing the impacts of global changes on the water resources of the Mediterranean basin", vol. 347, pp. 165-172, 2011.

[10] G.Ya. Ostaev, B.N. Khosiev, E.V. Nekrasova, O.Yu. Frantsisko, E.V. Markovina, L.M. Kubatieva, "Improving the methodology for assessing the efficiency of labor in the organization of the agro industrial complex: strategic accounting and analysis", Indo Amer. J. of Pharmac. Sci., vol. 6, no. 5, pp. 9114-9120, 2019.

[11] G.I. Panaedova, T.A. Kulagovskaya, Cheprakova T.N., E.V. Yakubova, "Food security problems and imperatives of the North Caucasus macro- 
region subjects”, Europ. Res. Studies J., iss. 21 (spec. Iss. 1), pp. 359-370, 2018.

[12] D.Ya. Petrova, N.V. Nesterova, N.P. Zaitseva, "Rating evaluation of the effectiveness of agricultural districts of the region", Innovat. development of the econ., vol. 3, no. 45, pp. 261-270, 2018.

[13] A. Shuvaev, O. Butova, V. Lebedev, I. Lebedeva, T. Skrebtsova, "Modeling and forecasting socio-economic processes in the region", Indo Amer. J. of Pharmac. Sci., vol. 6, no. 4, pp. 7082-7086, 2019.

[14] Yu.M. Sklyarova, I.Yu. Sklyarov, L.A. Latysheva, L.Yu. Piterskaya, S.V. Zenchenko, "Theoretical and methodological features the investment analysis of the economy agricultural sector", Indo Amer. J. of Pharmac. Sci., vol. 6, no. 3, pp. 5603-5610, 2019.

[15] T.A. Sycheva, A.Yu. Gusev, "Priority areas of investment activity in the region", Agricult. Econ. of Russ., no. 4, 2018.

[16] A.S. Scherbakova, "Rating assessment of the socio-economic potential of rural territories of the North", AIC: Econ., Manag., no. 1, pp. 56-64, 2020.

[17] V.G. Zakshevskiy, I.F. Khitskov, O.G. Charykova, Strategic directions for agricultural development in the Voronezh region. Voronezh: Res. Instit. of econ. and organizat. and agro-industr. complex of the Central Black-soil area of Russ., 2017, 212 p. 